\title{
The G2019S LRRK2 Mutation is Rare in Korean Patients with Parkinson's Disease
}

\author{
Jin-Whan Cho, Sung-Yeon Kim, Sung-Sup Park, Han-Jun Kim, Tae-Beom Ahn, \\ Jong-Min Kim, Beom-Seok Jeon
}

\begin{abstract}
Background: A number of causative mutations such as $\alpha$-synuclein, parkin, UCHL1, Pink-1, DJ-1 have been identified in Parkinson's disease (PD). They are usually found in the familial cases. One mutation of great interest is the G2019S mutation in the LRRK2 gene, which has been reported in both familial and sporadic PD. Its prevalence has been reported to vary markedly among different races. We examined the prevalence of the G2019S mutation in the Korean PD population for genetic study planning. Methods: We conducted a genetic analysis of the G2019S mutation by standard PCR and restriction digestion method. 453 PD patients were studied, 34\% of whom had an age at onset of $<50$ years and $3.8 \%$ had a positive family history. Results: None of the 453 study subjects carried the G2019S mutation. Conclusions: Our result confirms previous reports that the G2019S mutation is rare among PD patients in the Asian population. This result supports the notion that the prevalence of this LRRK2 mutation is population specific, and that there may be a founder effect within western populations.
\end{abstract}

\begin{abstract}
RÉSUMÉ: La mutation G2019S LRRK2 est rare chez les patients coréens atteints de la maladie de Parkinson. Contexte : Quelques mutations causales ont été identifiées dans la maladie de Parkinson (MP) telles des mutations des gènes de l'a-synucléine, de la parkine, de l'UCHL1, de la Pink-1 et de la DJ-1. Il s'agit habituellement de cas familiaux. La mutation G2019S du gène LRRK2, qui a été rapportée chez des cas familiaux de MP et chez des cas sporadiques, est très intéressante. Sa prévalence varie beaucoup selon la race. Nous avons examiné la prévalence de la mutation G2019S dans la population coréenne de patients atteints de la maladie de Parkinson afin de planifier une étude génétique. Méthodes : Nous avons réalisé une analyse génétique de la mutation G2019S par la méthode standard d'amplification en chaîne par polymérase et digestion par enzyme de restriction. 453 patients atteints de MP ont été étudiés. L'âge de début était < 50 ans chez $34 \%$ des patients et 3,8\% avaient une histoire familiale de MP. Résultats : Aucun des 453 patients n'était porteur de la mutation G2019S. Conclusions : Nos résultats confirment des publications antérieures selon lesquelles la mutation G2019S est rare chez les patients atteints de la MP dans la population asiatique. Ce résultat appui la notion que la prévalence de cette mutation du gène LRRK2 est spécifique de la population et qu'il pourrait exister un effet fondateur dans les populations occidentales.
\end{abstract}

Can. J. Neurol. Sci. 2007; 34: 53-55

A number of causative mutations of Parkinson's disease (PD) such as $\alpha$-synuclein, parkin, UCHL1, Pink-1, DJ-1 have been identified. ${ }^{1}$ The discovery of such genetic abnormalities has provided insights into the molecular pathogenesis of PD. These mutations are usually found in the familial cases. Recently, mutations in the LRRK2 gene have been reported to cause autosomal dominant PD (PARK8). ${ }^{2,3}$ The locus, PARK8 on chromosome $12 \mathrm{q} 12$, was originally identified by linkage analysis in a large Japanese family. ${ }^{4}$ The heterozygous mutation, G2019S, appears to be particularly common in Caucasian populations, and has been widely reported to account for about $3-7 \%$ of familial PD. ${ }^{5-9}$ Of great interest is that the G2019S mutation in LRRK2 may be present in about $0.9-2.7 \%$ of sporadic PD cases, and patients tend to share the clinical feature of typical, late-onset PD. ${ }^{5,10-12}$

From the Departments of Neurology (JWC, HJK, TBA, JMK, BSJ), Laboratory Medicine (SYK, SSP), BK-21 and MRC, College of Medicine, Seoul National University; Kyeong-Hee University (TBA); Boramae City Hospital (JWC); Seoul National University Hospital (SYK, SSP, HJK, BSJ); Bundang Hospital (JMK), Seoul, South Korea.

Received June 27, 2006. Accepted in final form September 27, 2006. Reprint requests to: Beom-Seok Jeon, Department of Neurology, Seoul National University College of Medicine, 28 Yeongeon-Dong, Jongno-Gu, Seoul, 110-744, South Korea. 
The observation that the prevalence of the LRRK2 mutation may vary with race is also of considerable interest. According to previous reports, the frequency of LRRK2 mutations in north African Arabs, Jews, and some Spanish are 6.1-41\% in sporadic $\mathrm{PD}$ and $18.7-37 \%$ in familial PD. ${ }^{13-15}$ In Asia, this mutation is rare in PD. ${ }^{16,17}$ Among the 16 mutations reported in LRRK2related PD, G2019S appears to be the most common. ${ }^{9-11,18,19}$

Therefore, we performed a genetic analysis for this mutation in 453 PD patients to determine the prevalence of the G2019S mutation in LRRK2 in Korean population.

\section{Patients and Methods}

All patients fulfilled criteria for a clinical diagnosis of PD (1. at least two of the three cardinal signs of tremor, rigidity, and bradykinesia. 2. a positive response to adequate dopaminergic therapy. 3. absence of atypical features or other causes of parkinsonism).

The Institutional Review Board (IRB) of Seoul National University Hospital approved this study. Written informed consent was obtained from all participants.

Four hundred and fifty three PD cases (M: 209, F: 244) were included in the study. Their onset age ranged 22-79 with a mean onset of $54.1 \pm 11.4$ years. The 154 patients $(34 \%)$ had onset at $\leq 50$ years of age, and 299 patients $(66 \%)$ had onset at $>50$ years of age. Seventeen cases had a positive family history of at least one other affected first degree relative.

DNA was extracted from peripheral blood using standard methodologies. We used a $50 \mathrm{ng}$ DNA template and generated PCR products using the following primer pair (forward: 5'AAGGGACAAAGTGAGCACAGA-3'; reverse: 5'TGTTTTCCTTTTGACTCTTCTGA-3' based on NCBI accession number NC_000012.10). The PCR conditions were initial denaturation at $95^{\circ} \mathrm{C}$ for 10 minutes, and 35 cycles of $95^{\circ} \mathrm{C}$ for 30 seconds, $60^{\circ} \mathrm{C}$ for 30 seconds, and $72^{\circ} \mathrm{C}$ for 1 minute, and a final extension at $72^{\circ} \mathrm{C}$ for 7 minutes. PCR products ( $3 \mathrm{uL}$ ) were digested with SfcI (New England BioLabs, Beberly, MA, USA) at $37^{\circ} \mathrm{C}$.

Wild type products produced fragments of $251 \mathrm{bp}$ and $127 \mathrm{bp}$ and the mutant could produce fragments of $230 \mathrm{bp}, 127 \mathrm{bp}$ and $21 \mathrm{bp}$. Since we did not have a positive control, we used the 677C $>$ T mutant DNAs of the MTHFR gene with similar fragments sizes (175 bp and $23 \mathrm{bp}$ ) for the quality control of restriction digestion and electrophoretic separation.

\section{RESUlts}

None of the 453 study subjects carried the G2019S mutation.

\section{Discussion}

Mutations in LRRK2 appear to be the most common cause of autosomal-dominantly inherited parkinsonism known to date. Unlike other causative mutations of PD, mutations within LRRK2 have been identified in some percentage of sporadic and late-onset PD, which suggests that LRRK2 makes a unique contribution to the development of PD. The heterozygous mutation, G2019S, appears to be particularly common in Caucasian populations. It accounts for 3-7\% of familial PD and may be present in about $0.9-2.7 \%$ of sporadic PD cases in the western populations. ${ }^{5-12}$ Surprisingly, the frequencies of the
G2019S mutations in North Africa were 37\% (10/27) among patients with a family history, and $41 \%$ (20/49) in those without. ${ }^{13}$ In Askenazi Jews, the G2019S mutation in LRRK2 was found in $19.7 \%(11 / 37)$ with familial PD and in $13.3 \%$ $(11 / 83)$ with sporadic PD. ${ }^{14}$ However, Bialecka et al reported finding no mutation in a Polish population of 174 PD. ${ }^{20}$

A few studies on LRRK2 mutations have been reported in Asian PD patients, and suggest that LRRK2 mutation is rare in this population. Funayama et al and Tan et $\mathrm{al}^{17}$ reported the absence of the G2019S mutation in 188 Japanese $^{4}$ and 675 Chinese respectively. Lu et $\mathrm{al}^{16}$ reported that none of the 624 ethnic Chinese with sporadic PD carried any of the G2019S, I2020T, I2012T mutations.

Our finding confirms previous reports that the G2019S mutation is rare among patients with sporadic PD in the Asian population supporting that the prevalence of the LRRK2 mutation is population specific and that there may be a founder effect within those populations with high reported prevalence of this mutation. In the present study, we screened for the G2019S mutation only. As the G2019S mutation is the most common $^{9-11,18,19}$ among the 16 mutations reported in LRRK2related $\mathrm{PD}$, routine testing for LRRK2 mutations may not be cost-effective in the Asian population based on our and previous results. However, a wider search other LRRK2 mutations is needed to fully examine the contribution of this gene in our population.

\section{ACKNOWLEDGMENTS}

This study was supported by Grant No. 05-2005-005 from the Seoul National University Hospital research fund.

\section{REFERENCES}

1. Hofer A, Gasser T. New aspects of genetic contributions to Parkinson's disease. J Mol Neurosci. 2004;24:417-24.

2. Paisan-Ruiz C, Jain S, Evans EW, van der Brug M, de Munain AL, Aparicio S, et al. Cloning of the gene containing mutations that cause PARK8-linked Parkinson's disease. Neuron. 2004;44: 595-600.

3. Zimprich A, Biskup S, Leitner P, Lichtner P, Farrer M, Lincoln S, et al. Mutations in LRRK2 cause autosomal-dominant parkinsonism with pleomorphic pathology. Neuron. 2004; 44:601-7.

4. Funayama M, Hasegawa K, Ohta E, Kawashima N, Komiyama M, Kowa $\mathrm{H}$, et al. An LRRK2 mutation as a cause for the Parkinsonism in the original PARK8 family. Ann Neurol. 2005;57:918-21.

5. Aasly JO, Toft M, Fernandez-Mata I, Kachergus J, Hulihan M, White LR, et al. Clinical features of LRRK2-associated Parkinson's disease in central Norway. Ann Neurol. 2005; 57:762-65.

6. Bras JM, Guerreiro RJ, Ribeiro MH, Januario C, Morgadinho A, Oliveira CR, et al. G2019S Dardarin substitution is a common cause of Parkinson's disease in a Portuguese cohort. Mov Dis. 2005;20:1653-55.

7. Fonzo AD, Rohe CF, Ferreira J, Chien HF, Vacca L, Stocchi F, et al. A frequent LRRK2 gene mutation associated with autosomal dominant Parkinson's disease. Lancet. 2005;365:412-15.

8. Gilks WP, Abou-Sleiman PM, Gandhi S, Jain S, Singleton A, Lees A, et al. A common LRRK2 mutation in idiopathic Parkinson's disease. Lancet. 2005;365:415-16.

9. Zabetian CP, Samii A, Mosley AD, Roberts JW, Leis BC, Yearout $\mathrm{D}$, et al. A clinic-based study of the LRRK2 gene in Parkinson disease yields new mutations. Neurology. 2005;65:741-4. 
10. Goldwurm S, Fonzo AD, Simons EJ, Rohe CF, Zini M, Canesi M, et al. The G6055A(G2019S) mutation in LRRK2 is frequent in both early and late onset Parkinson's disease and originates from a common ancestor. J Med Genet. 2005;42:e65.

11. Kay DM, Zabetian CP, Factor SA, Nutt JG, Samii A, Griffith A, et al. Parkinson's disease and LRRK2: frequency of a common mutation in U.S. movement disorder clinics. Mov Dis.2006; 21:519-23.

12. Mata IF, Taylor JP, Kachergus J, Hulihan M, Huerta C, Lahoz C, et al. LRRK2 R1141G in Spanish patients with Parkinson's disease. Neurosci lett. 2005;382:309-11.

13. Lesage S, Durr A, Tazir M, Lohmann E, Leutenegger AL, Janin S, et al. LRRK2 G2019S as a cause of Parkinson's disease in North African Arabs. N Engl J Med. 2006 Jan 26;354:422-3.

14. Ozelius LJ, Senthil G, Saunder-Pullman R, Ohmann E, Deligtisch A, Tagliati M, et al. LRRK2 G2019S as a cause of Parkinson's disease in Ashkenazi Jews. N Engl J Med. 2006; 354:424-5.

15. Infante J, Rodriguez E, Combarros O, Mateo I, Fontalba A, Pascual $\mathrm{J}$, et al. RRK2 G2019S is a common mutation in Spanish patients with late-onset Parkinson's disease. Neurosci Lett 2006; 395:224-6.
16. Lu CS, Simons EJ, Wu-Chou YH, Fonzo AD, Chang HC, Chen RS, et al. The LRRK2 I2012T, G2019S, and I2020T mutations are rare in Taiwanese patients with sporadic Parkinson's disease. Parkinsonism Relat Disord. 2005;11:521-2.

17. Tan EK, Shen H, Tan LCS, Farrer M, Yew K, Chua E, et al. The G2019S LRRK2 mutation in uncommon in an Asian cohort of Parkinson's disease patients. Neurosci lett. 2005;384:327-9.

18. Brice A. Genetics of Parkinson's disease. LRRK2 on the rise. Brain. 2005;128:2760-2.

19. Kachergus J, Mata IF, Hulihan M, Taylor JP, Lincoln S, Aasly J, et al. Identification of a novel LRRK2 mutation linked to autosomal dominant parkinsonism: evidence of a common founder across European populations. Am J Hum Genet. 2005;76: 672-80.

20. Bialecka M, Hui S, Duda GK, Opala G, Tan EK, Drozdzik M. Analysis of LRRK2 G2019S and I2020T mutations in Parkinson's disease. Neurosci letter. 2005;390:1-3. 